\title{
Brain death induces renal expression of heme oxygenase- 1 and heat shock protein 70
}

\author{
Leon FA van Dullemen ${ }^{1 *}$, Eelke M Bos ${ }^{2}$, Theo A Schuurs ${ }^{1}$, Harm H Kampinga ${ }^{3}$, Rutger J Ploeg ${ }^{1}$, \\ Harry van Goor ${ }^{2}$ and Henri GD Leuvenink'
}

\begin{abstract}
Background: Kidneys derived from brain dead donors have lower graft survival and higher graft-function loss compared to their living donor counterpart. Heat Shock Proteins (HSP) are a large family of stress proteins involved in maintaining cell homeostasis. We studied the role of stress-inducible genes Heme Oxygenase-1 (HO-1), HSP27, HSP40, and HSP70 in the kidney following a 4 hour period of brain death.

Methods: Brain death was induced in rats $(n=6)$ by inflating a balloon catheter in the epidural space. Kidneys were analysed for HSPs using RT-PCR, Western blotting, and immunohistochemistry.

Results: RT-PCR data showed a significant increase in gene expression for HO-1 and HSP70 in kidneys of brain dead rats. Western blotting revealed a massive increase in $\mathrm{HO}-1$ protein in brain dead rat kidneys.

Immunohistochemistry confirmed these findings, showing extensive HO-1 protein expression in the renal cortical tubules of brain dead rats. HSP70 protein was predominantly increased in renal distal tubules of brain dead rats treated for hypotension.

Conclusion: Renal stress caused by brain death induces expression of the cytoprotective genes HO-1 and HSP70, but not of HSP27 and HSP40. The upregulation of these cytoprotective genes indicate that renal damage occurs during brain death, and could be part of a protective or recuperative mechanism induced by brain death-associated stress.
\end{abstract}

Keywords: Kidney, Protective genes, Rat, Organ donation, HSP, HSP70, HSP40, HSP27

\section{Background}

Renal transplantation leads to a significantly improved prognosis for the majority of patients with end-stage renal disease. Most kidneys used for renal transplantation are derived from brain dead donors. These kidneys, however, are known to have inferior organ quality and survival compared to kidneys from living related donors [1,2]. The knowledge on the (patho)-physiological processes initiated by brain death that are responsible for this observation are not fully elucidated. Previous studies indicated that the brain death causes marked inflammatory changes in peripheral organs [3] and incites various (patho)-physiological processes, like hemodynamic instability [4] and hormone dysregulation [5]. The inflammatory changes in liver and

\footnotetext{
* Correspondence: I.f.a.van.dullemen01@umcg.nl

'Departments of Surgery, University Medical Center Groningen, University of Groningen, Hanzeplein 1, PO Box 30.001, 9700 RB Groningen, The Netherlands

Full list of author information is available at the end of the article
}

kidney, as evidenced by an increase in $\mathrm{CD} 45^{+}$leukocytes, coincide with upregulation of cell adhesion molecule expression (ICAM-1, VCAM-1, E-selectin) and apoptosis [6-9]. The hemodynamic instability, displayed by a short hypertensive phase at the onset of brain death followed by a decline in blood pressure to normal tension or hypotension, could cause poor organ perfusion and thereby an inadequate oxygen delivery to the peripheral tissues, resulting in organ damage.

Heat-shock proteins (HSP) are a diverse group of proteins involved in cellular homeostasis and display cytoprotective effects in different forms of stress, mostly ascribed to their role as molecular chaperones. HSPs act in, for example, protein folding, protein assembly, protein aggregation, intracellular transport, and degradation of damaged substances (for review, see references $[10,11]$ ). It has been shown that heat-shock proteins, which are numbered according to their approximate molecular mass in
C Biomed Central

(c) 2013 van Dullemen et al.; licensee BioMed Central Ltd. This is an Open Access article distributed under the terms of the Creative Commons Attribution License (http://creativecommons.org/licenses/by/2.0), which permits unrestricted use, distribution, and reproduction in any medium, provided the original work is properly cited. 
$\mathrm{kDa}$, have a protective role in ischemia/reperfusion injury by repairing damaged proteins and thereby removing the stimulus for apoptosis [10,12-20]. Upregulation of HSP70 prior to transplantation improves graft survival and function [19-22]. Selective upregulation of heme oxygenase-1 (HO-1, also known as HSP32) has shown similar graftprotective effects in the kidney, heart and liver [23-27]. Furthermore, HO-1 has immunosuppressive characteristics $[25,28,29]$, that are likely mediated in part by production of carbon monoxide $(\mathrm{CO})$ during heme degradation, which possibly induces vasodilatation and attenuates proinflammatory processes during brain death.

There is only very limited knowledge about the effects of brain death on the expression of HSPs in the kidney. To evaluate possible renal recuperative and/or protective mechanisms induced during brain death, we studied kidneys from rats exposed to a 4 hour period of brain death for presence of HSP27, HSP40, HSP70, and HO-1 protein and mRNA.

\section{Methods \\ Animals}

Adult male Fisher F344 rats weighing 278-310 grams were used (Harlan, Horst, The Netherlands) in this study. Average weight was $285 \pm 18$ grams. The rats were housed in a light- and temperature-controlled environment and had free access to food and water. All animals received care in compliance with the guidelines of the local animal ethics committee according to Experiments on Animals Act (1996) issued by the Ministry of Public Health, Welfare and Sports of the Netherlands.

\section{Brain death induction}

Rats were anesthetized using isoflurane with a mixture of $\mathrm{NO}_{2}$ and $\mathrm{O}_{2}$ during brain death induction. They were intubated via a tracheostomy by a blunt-tipped cannula and mechanically respirated. The animals were ventilated on a small rodent ventilator (Zoovent, Triumph Technical Services Ltd, UK) with 4 liter/min $\mathrm{O}_{2}$ in air for $30 \mathrm{~min}$ (stroke rate: 46 per $\mathrm{min}$, inspiration/expiration: $1 / 2$, peak inspiratory pressure: $16 \mathrm{mmHg}$, mean inspiratory pressure: $6 \mathrm{mmHg}$, and a positive end expiratory pressure: $0 \mathrm{mmHg}$ ). After that, they were ventilated with $0.5 \mathrm{liter} / \mathrm{min} \mathrm{O}_{2}$ in air until the end of the brain death period.

Brain death induction was performed by drilling a $1 \times 1 \mathrm{~mm}$ hole through the frontomedial part of the skull, just lateral of the central vein. A no.4 Fogarty catheter (Edwards Life Sciences Co., Irvine, CA, USA) was inserted in the epidural space with the tip pointing caudally. To simulate an epidural haematoma leading to brain death, intracranial pressure was increased gradually by slow inflation of the balloon (16 $\mu \mathrm{l}$ saline per min) using a syringe pump (Terufusion, Termo Co., Tokyo, Japan). Inflation of the balloon was stopped after approximately $25 \mathrm{~min}$, when the blood pressure reached normal levels after an initial phase of hypotension. During balloon inflation, the sharp rise of blood pressure that is typical in brain death development was seen. Brain death was verified 30 minutes after the start of balloon inflation by an apnoea test, confirmation of dilated and fixed pupils and the absence of corneal reflexes. The average balloon volume that consistently induced brain death was $(420 \pm 20 \mu \mathrm{l})$. The balloon was kept inflated during the entire experiment. Blood pressure was monitored via a PE cannula $(0.40 \times 0.80 \mathrm{~mm})$ implanted in the left femoral artery. Blood pressure above $80 \mathrm{mmHg}$ was considered normotensive. When blood pressure dropped beneath $80 \mathrm{mmHg}$, rats were infused with $10 \%$ hydroxyethyl starch (HAES) until normotension was reached. Body temperature, measured with a rectal thermoprobe (Mon-a-therm 6510, Mallinckrodt Medical, Inc., St. Louis, MO, USA), was maintained at $37^{\circ} \mathrm{C}$ by means of a heating pad and lamp.

After 4 hours of brain death, isoflurane $0.5 \%$ anaesthesia with a mixture of $\mathrm{NO}_{2}$ and $\mathrm{O}_{2}$ was used 10 minutes before the end of the brain death period to achieve full muscle relaxation in order to allow abdominal surgery. Left kidneys were removed after perfusion with cold saline and cut in two sections, one part was snap frozen in liquid nitrogen, the other part was fixated in $4 \%$ paraformaldehyde.

\section{RNA isolation and semi quantitative RT-PCR}

Total RNA was isolated from snap frozen renal tissue using the SV Total RNA Isolation System (Promega, Madison, Wisconsin, USA) according to the manufacturer's protocol. Briefly, cDNA synthesis from total RNA included an initial step in which $1 \mu \mathrm{g}$ of RNA is incubated with $\mathrm{T}_{11} \mathrm{VN}$ oligo's $(0.5 \mu \mathrm{g})$ for 10 minutes at $70^{\circ} \mathrm{C}$. Subsequently, buffer, dNTP's (final conc. $1 \mathrm{mM}$ ), DTT (final conc. $10 \mathrm{mM}$ ), $200 \mathrm{U}$ M-MLV Reverse Transcriptase and $20 \mathrm{U}$ RNaseOUT $^{\mathrm{TM}}$ Recombinant Ribonuclease Inhibitor (all from Invitrogen, Carlsbad, California, USA) were added and incubated for $50 \mathrm{~min}$ at $37^{\circ} \mathrm{C}$, after which the reaction was inactivated by a 15 min incubation at $70^{\circ} \mathrm{C}$. Two $\mu$ l of cDNA was amplified by PCR in a buffer consisting of $0.2 \mathrm{mM}$ dNTP's, $1.5 \mathrm{mM} \mathrm{MgCl}_{2}, 1 \mathrm{x}$ PCR buffer and $1 \mathrm{U}$ Taq DNA polymerase (all from Invitrogen). Gene-specific primer pairs (0.5 $\mu \mathrm{M}$ each) were added directly, after which they were heated for $3 \mathrm{~min}$ at $94^{\circ} \mathrm{C}$. PCR was performed on a $\mathrm{T} 1$ Thermocycler (Biometra) and cycles consisted of $94^{\circ} \mathrm{C}$ for $40 \mathrm{~s}$, a primer annealing temperature at $56^{\circ} \mathrm{C}$ for $40 \mathrm{~s}$ and a polymerization step at $72^{\circ} \mathrm{C}$ for $40 \mathrm{~s}$. The numbers 
of cycles were selected to allow amplification within the linear range.

The primer sequences, the number of cycles and their respective PCR fragment lengths were:

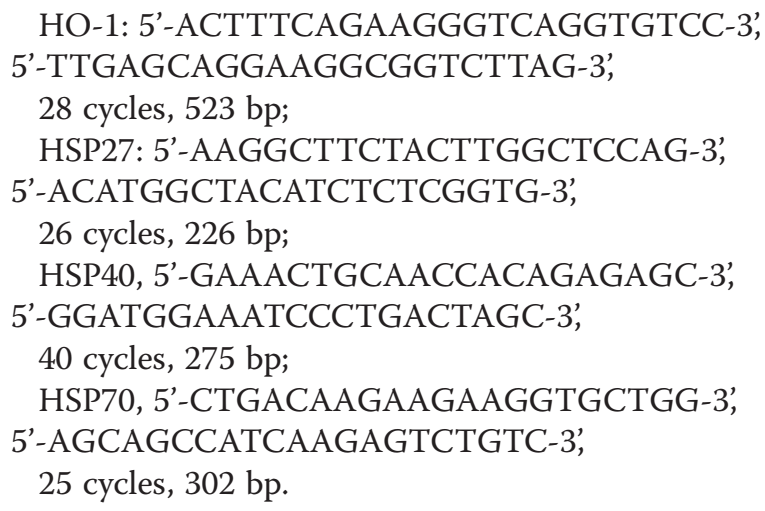

Primer pairs were developed using Primer3 (http://bioinformatics.weizmann.ac.il/cgi-bin/primer/primer3.cgi). Ethidium bromide-stained agarose gels were scanned on Image Master ${ }^{\circledR}$ VDS (Amersham Biosciences, UK) using LISCAP software. PCR product abundance was quantified using Imagemaster 1D Elite (Amersham) and normalized for the abundance of the $\beta$-actin signal from the same cDNA.

\section{Western blotting}

Per sample, three $20 \mu \mathrm{m}$ cryostat sections were lysed in 200 $\mu \mathrm{L}$ RIPA buffer $\left(1 \% \mathrm{NP}_{40}, 0.1 \%\right.$ SDS, $10 \mathrm{mM} \beta$-mercaptoethanol) containing protease inhibitors (Complete, Roche). Samples were lysed on ice, centrifuged for $15 \mathrm{~min}$ at $16000 \mathrm{~g}$ $\left(4^{\circ} \mathrm{C}\right)$ and supernatants collected. Protein concentrations were measured using the Lowry Protein assay (BioRad). 7.5 $\mu \mathrm{g}$ of total protein was separated by SDS-PAGE (Sodium Dodecyl Sulphate PolyAcrylamide Gel Electrophoresis) on $10 \%$ polyacrylamide gels using the BioRad electrophoresis system. Proteins were electroblotted (BioRad blotting system) onto PVDF membranes (Hybond, Amersham) after which immune detection was performed. Briefly, membranes were blocked in PBS $\left(6.5 \mathrm{mM} \mathrm{Na} \mathrm{HPO}_{4}, 1.5 \mathrm{mM}\right.$ $\mathrm{KH}_{2} \mathrm{PO}_{4}, 2.7 \mathrm{mM} \mathrm{KCl}$ and $150 \mathrm{mM} \mathrm{NaCl}$; $\mathrm{pH}$ 7.2) with 0.05\% Tween (PBST) containing 5\% SKIM, overnight. Incubation with primary antibodies directed to HSP27 (SPA-801), HSP40 (SPA-400), HSP70 (SPA-810) and HO-1 (OSA-111, all by StressGen, Victoria, BC, Canada) for 2 hours was followed by $1 \mathrm{hr}$ incubation with an appropriate secondary antibody conjugated to peroxidase in blocking buffer at 1:2000 dilution. After each incubation step, membranes were washed 5 times in PBST. Bound antibodies were detected with ECL Western blotting detection system (Amersham, UK) according to the manufacturer's protocols. Detected signal was quantified and normalized for the GAPDH signal on the same blot.

\section{Immunohistochemistry}

For localization of HSP40, HSP70 and HO-1, paraffin sections $(4 \mu \mathrm{m})$ were de-waxed, rehydrated and subjected to heat-induced antigen retrieval by microwave heating in 10 $\mathrm{mM}$ citrate buffer ( $\mathrm{pH}=6.0, \mathrm{HSP} 40), 1 \mathrm{mM}$ EDTA $(\mathrm{pH}=8.0, \mathrm{HSP} 70)$, or by overnight incubation in $0.1 \mathrm{M}$ Tris/ $\mathrm{HCl}$ buffer at $80^{\circ} \mathrm{C}(\mathrm{pH}=9.0, \mathrm{HO}-1)$. Endogenous peroxidase was blocked with $0.03 \% \mathrm{H}_{2} \mathrm{O}_{2}$ in phosphatebuffered saline (PBS) for 30 minutes. Primary antibodies used were identical to those used in Western blotting. Incubation lasted for $60 \mathrm{~min}$ at RT and binding of the antibody was detected by sequential incubation with appropriate peroxidase-labelled secondary and tertiary antibodies (Dakopatts, Glostrup, Denmark) for $30 \mathrm{~min}$. Antibody dilutions were made in phosphate-buffered saline (PBS) supplemented with $1 \%$ bovine serum albumin (BSA) and $1 \%$ normal rat serum. The peroxidase activity was visualised using 3,3'-diaminobenzidine tetrahydrochloride (DAB+, cat. no. K3468; DAKO). Finally, sections were counterstained with haematoxylin.

For HSP27 staining, cryostat sections $(4 \mu \mathrm{m})$ were fixed in acetone for $10 \mathrm{~min}$. Subsequently, they were dried and incubated with the primary antibody (SPA801, StressGen) for $60 \mathrm{~min}$ at RT. Endogenous peroxidase was blocked with $0.0075 \% \mathrm{H}_{2} \mathrm{O}_{2}$ in $\mathrm{PBS}$ for $30 \mathrm{~min}$. Detection of binding was performed as described above. Peroxidase activity was visualised using 3-amino-9-ethylcarbazole (AEC) for $15 \mathrm{~min}$. Sections were counterstained with haematoxylin.

\section{Statistical analysis}

Statistical analysis was performed using the two-sided Students $\mathrm{T}$ test, a $p$ value $<0.05$ was considered significant. Correlations between variables were assessed with one-way ANOVA. Statistical analyses were performed using SPSS version 18.0 (SPSS Inc, Chicago, US).

\section{Results}

\section{Semi-quantitative RT-PCR}

Renal expression of genes coding for HO-1 and HSP70 was significantly increased in kidneys of brain dead rats compared to living controls (Figure 1). For HO-1 the increase was 3.7 fold compared to controls $(\mathrm{p}<0.05)$, HSP70 was increased 2.4 fold $(\mathrm{p}<0.05)$. Differences in the expression of HSP27 and HSP40 were not observed (Figure 1). Rats treated with substantial volumes of hydroxyethyl starch (1.0-5.75 $\mathrm{mL}, \mathrm{n}=3)$ for blood pressure regulation showed a 3.8 fold $(\mathrm{p}<0.05)$ increased expression of HSP70 compared to control rats. Rats treated with scant volumes of hydroxyethyl starch (0-0.6 $\mathrm{mL}, \mathrm{n}=3$ ) showed a 1.7 fold increase, which was not significant $(\mathrm{p}=0.25)$. 

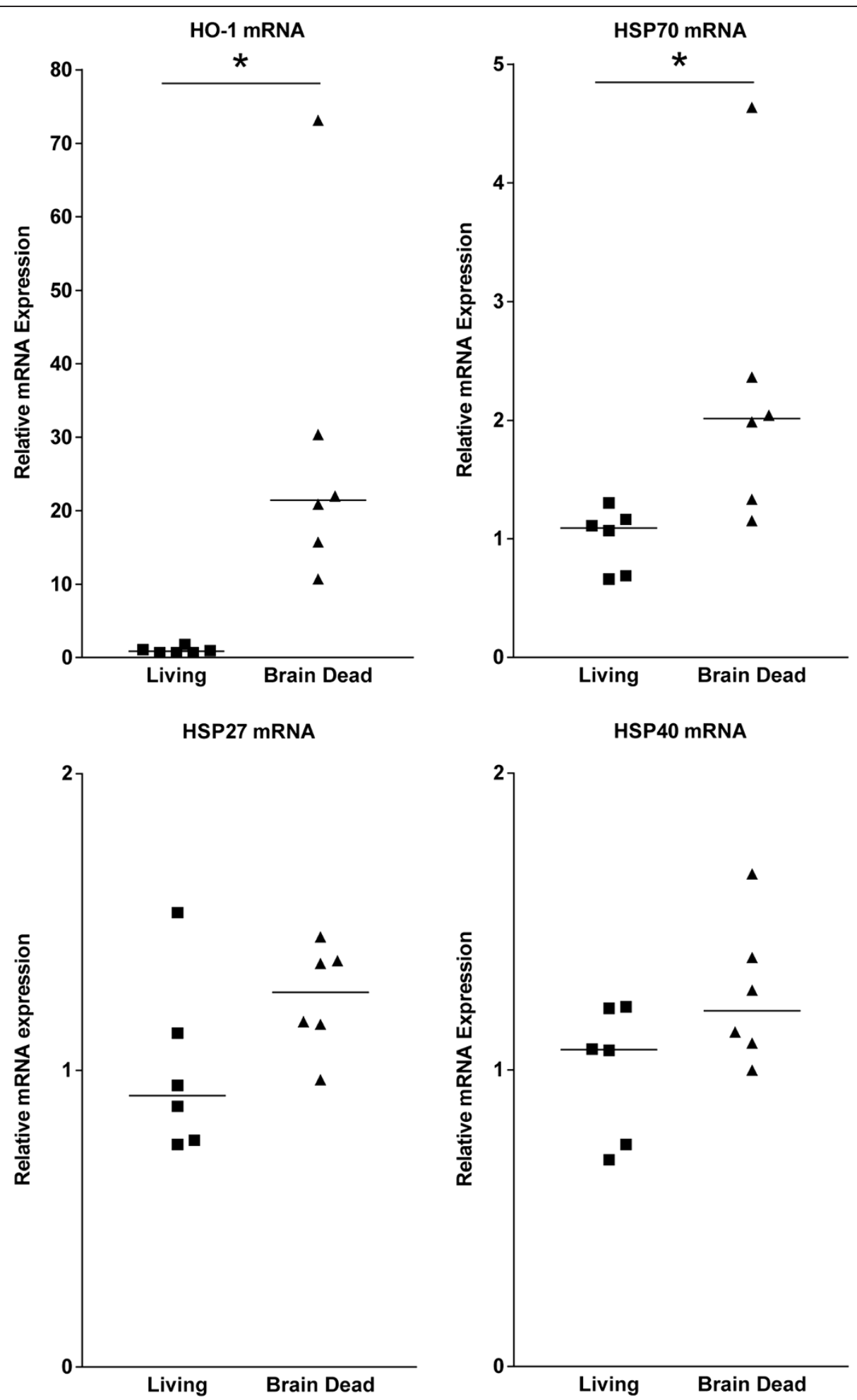

Figure 1 qPCR results showed a massive increase in renal HO-1 mRNA levels of brain dead rats. A significant increase in HSP70 expression was also seen. QPCR for HSP27 and HSP40 did not reveal differences in mRNA expression between control and brain dead groups. 


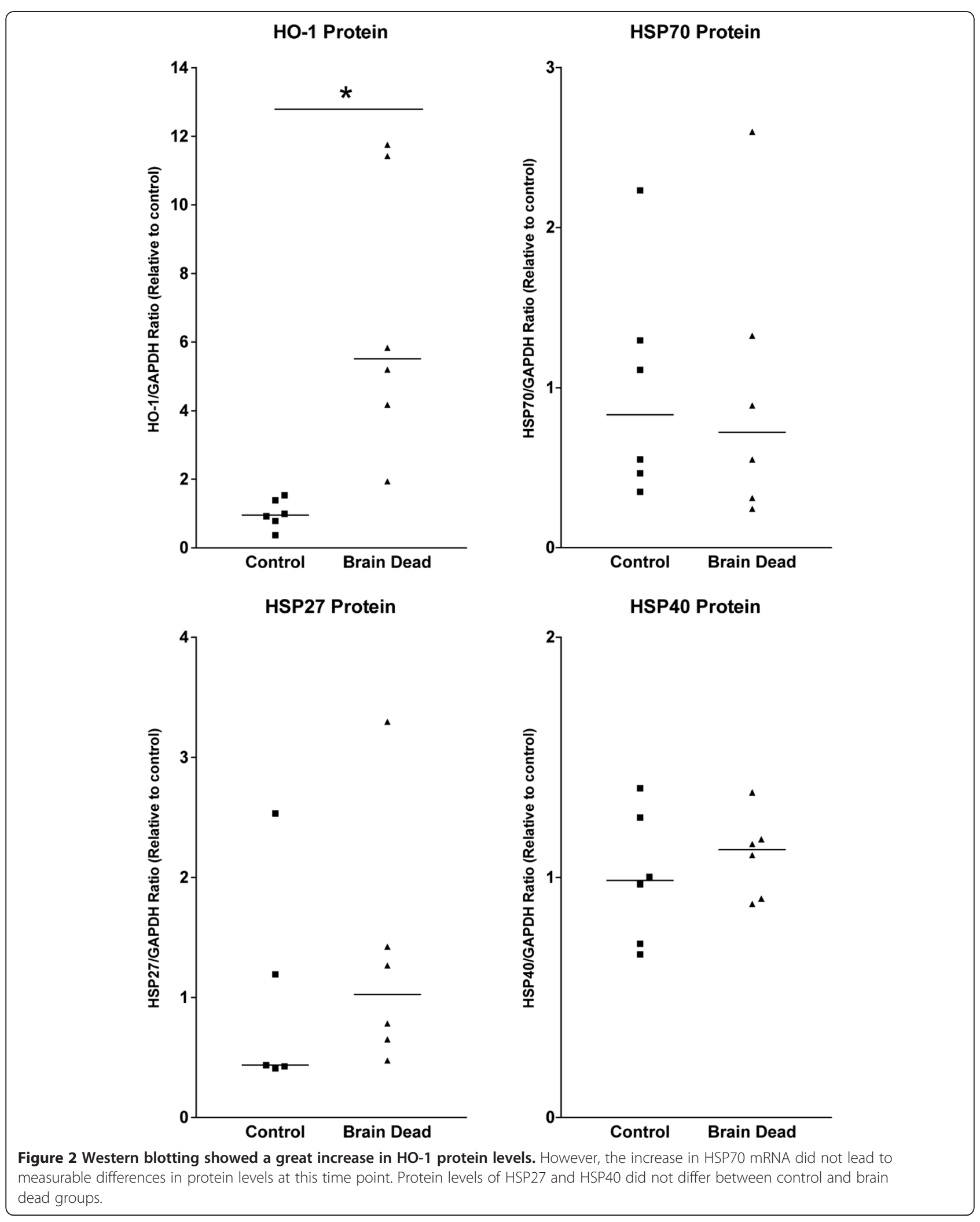




\section{Western blotting}

A 4.6 fold increase $(\mathrm{p}<0.001)$ in $\mathrm{HO}-1$ protein was observed in brain dead rat kidneys compared to living controls (Figure 2). Quantities of HSP70 protein did not differ in the brain dead group (Figure 2), and no differences were detected between the normotensive and hypotensive groups of brain dead rats. Levels of HSP27 and HSP40 protein showed no variation between brain dead and control groups (Figure 2), confirming data from immunohistochemistry. Furthermore, we found significant positive correlations between the protein expression of HSP70 and the protein expressions of HSP40 $\left(\mathrm{p}<0.05, \quad \mathrm{R}^{2}=0.38\right) \quad$ and HSP27 $\quad\left(\mathrm{p}<0.05, \quad \mathrm{R}^{2}=0.94\right)$ (Figure 3).

\section{Immunohistochemistry}

In control rats, weak cytoplasmatic HO-1 staining of some proximal tubules of the renal cortex was observed (Figure 4A). Glomeruli and arteries were negative, as well as the collecting ducts and loops of Henle. In brain dead rat kidneys at 4 hours after induction, $\mathrm{HO}-1$ was massively upregulated in the cortical proximal tubules (Figure 4B). Also, some solitary tubular cells showed very intense staining compared to adjacent cells (Figure 4D), which was not seen in controls (Figure 4C). Glomeruli were negative, with the exception of some solitary cells, which could be CD68-positive macrophages.

HSP70 staining was found in some single distal tubular cells. Glomeruli were stained negative for HSP70 (Figure 5A). Upregulation of HSP70 was predominantly seen in the renal distal tubules of the hypotensive rats treated with hydroxyethyl starch as a volume replacement, showing an increase in the number of positively stained single cells (Figure 5B). In rats that remained normotensive during brain death and thus were not treated with hydroxyethyl starch, no difference in staining of HSP70 compared to controls was detected.
HSP27 was present in vascular smooth muscle cells of renal arteries. Tubular staining was not detected, but some glomerular staining was evident.

HSP40 was detected in the glomeruli, with visceral and parietal epithelium stained positive. Also, some distal tubular and collecting duct staining was detected.

No detectable differences were found for HSP27 and HSP40 between the brain dead and control group, confirming Western blot results.

\section{Discussion}

The major finding of the present study is that systemic stress associated with brain death induces enhanced expression of protective genes in the donor kidney. These data are in line with previous micro-array data showing marked upregulation of various protective genes during experimental brain death [30]. Since $\mathrm{HO}-1$ is known to attenuate damage in various stress models, such as ischemia/reperfusion and experimental transplantation, we consider the significant increase of $\mathrm{HO}-1$ protein and mRNA in renal proximal tubules from brain dead rats a recuperative mechanism in response to the injury caused by the systemic effects of extensive brain injury.

Brain death induction can cause significant detrimental effects on various donor organs. The "autonomic storm", an immediate release of massive amounts of catecholamines into the blood stream, occurs directly after the onset of brain death. The hemodynamic changes cause altered perfusion of the kidneys, possibly resulting in ischemic damage [4,31]. As a result of brain death and its systemic effects increased pro-inflammatory reactivity in donor organs takes place, as evidenced by upregulation of cell adhesion molecules such as ICAM and selectins. The increments in adhesion molecules are associated with increased influx of inflammatory cells such as T-cells, macrophages and polymorphonuclear neutrophils. These early pro-inflammatory changes further progress to renal
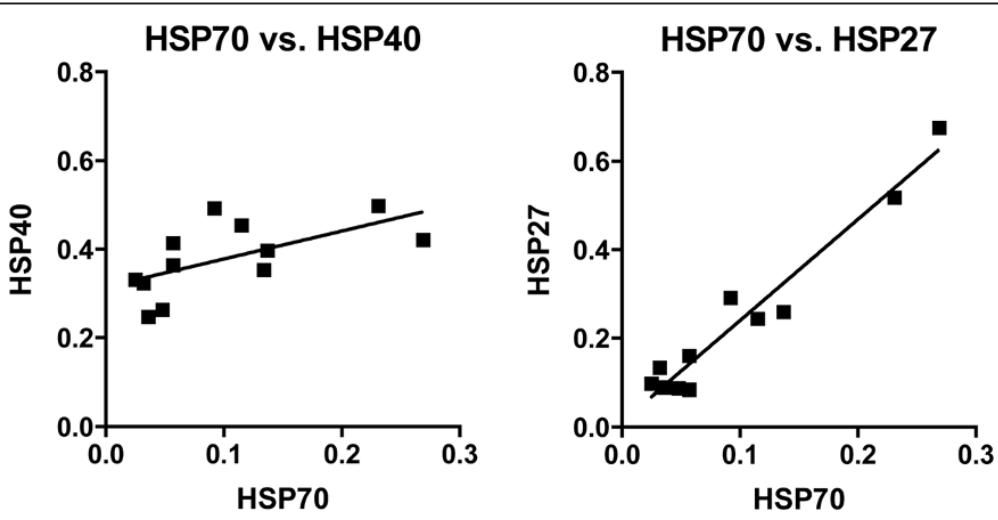

Figure 3 Renal Western blot results from living and brain dead rats for HSP70 protein expression was found to correlate significantly $\left(\mathbf{R}^{2}=\mathbf{0 . 3 8}\right)$ with HSP40 protein expression. $\mathrm{HSP70}$ protein expression was also found to correlate significantly $\left(\mathrm{R}^{2}=0.94\right)$ with HSP27 protein expression. 


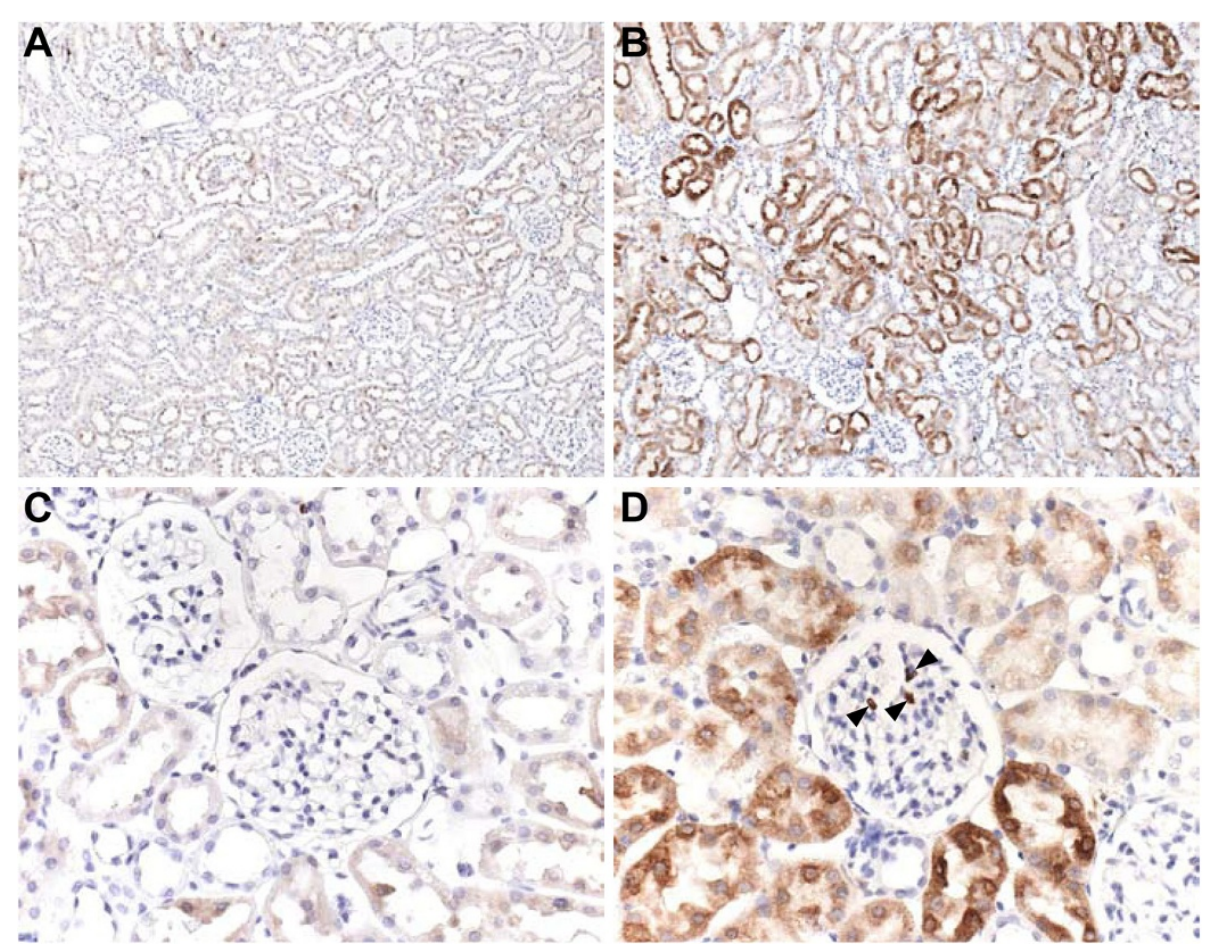

Figure 4 HO-1 immunohistochemistry staining on renal tissue from living $(A, C)$ and brain dead rats $(B, D)$ showed a significant increase in HO-1 protein in renal cortical tubules of the $4 \mathrm{~h}$ brain dead group (B, 100x) compared to the living group (A 100x). At a magnification of $400 \times(\mathbf{C}, \mathbf{D})$ it is apparent that there is an increase in $\mathrm{HO}^{-1}$ protein in a number of singular tubular cells of brain dead rats. Also, several positive cells can be observed in the glomerulus (D, Arrowheads) which could be CD68 ${ }^{+}$macrophages.

fibrotic damage, a decrease in renal function, and inferior graft survival $[7,32,33]$.

Using immunohistochemistry in control rat kidneys, we noted weak HO-1 staining in the proximal tubules, indicating a physiological role for HO-1 in the kidney. Basal expression of HO-1 in the normal human kidney, although weak, is also found in the renal proximal tubules [34] and in some $\mathrm{CD}^{+} 8^{+}$macrophages as is described by Takano et al. [35]. In human renal disease, proximal tubular induction of HO-1 is found in patients with focal segmental glomerulosclerosis and rapidly progressing glomerulonephritis [34]. Also, massive renal upregulation of HO-1 mRNA is seen after ischemic acute renal failure in rats [36], as well as in a model of acute renal allograft rejection [37]. Although the mechanism of HO-1 induction was not studied here, these data point to defensive tubular adaptations that are induced in response to the induction of brain death.

In the normal rat kidney, HSP70 protein is found following a pattern resembling the corticopapillary concentration gradient, showing more HSP70 expression in the hyperosmotic medulla of the kidney compared to the

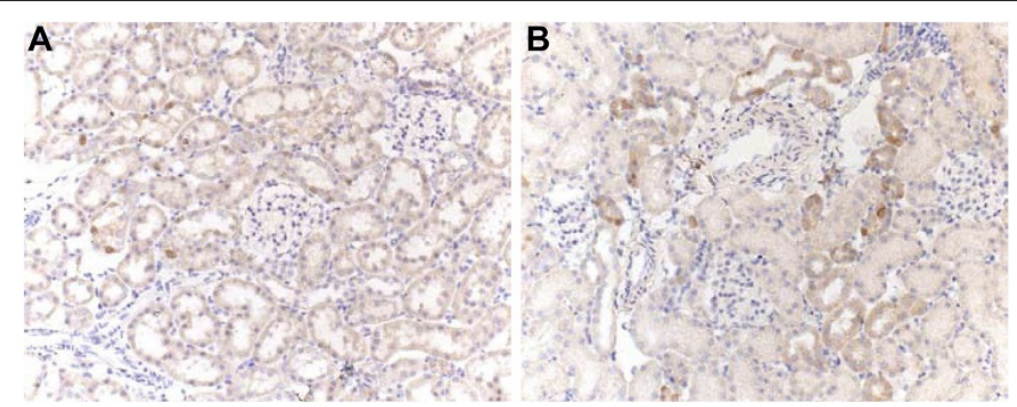

Figure 5 HSP70 immunohistochemistry staining on renal tissue from living (A) and brain dead rats (B) at 100x magnification shows a slight increase in staining in the renal cortical tubules of the brain dead rats. (B) Control kidneys showed only occasional positively stained singular cells in tubular structures. 
isosmotic cortex [38]. Enhanced expression of HSP70 was also induced during brain death. However, the increased expression of HSP70 on protein level was small as observed by immunohistochemistry, and could not be reproduced by Western blotting. This could be the result of the relatively small amount of HSP70 inducing cells. The increase in HSP70 expression was predominantly noted in animals which were treated with hydroxyethyl starch for hemodynamic instability during brain death. Hydroxyethyl starch infusion can cause renal tubule lesions [39], is an independent risk factor for acute renal failure during severe sepsis [40] and has a negative effect on the outcome of renal transplantation if administered to brain dead patients before graft retrieval [39]. Therefore, we can not be sure if the induction of HSP70 is attributable to effects of brain death, brain death induced hemodynamic instability, the infusion of hydroxyethyl starch or any combination of these factors. However, in other studies, brain death induced HSP70 mRNA expression in the heart [41] and kidney [30].

In previous studies HSP27 in the human kidney showed a weak expression pattern in the cortical collecting ducts, and strong expression in the medullary collecting ducts. This pattern, similar to the expression pattern of HSP70, suggests the influence of the osmotic gradient on the expression of HSP27 [42]. HSP70, HSP40 and HSP27 are HSF-1-regulated proteins [43], and the correlations found between HSP70 and HSP40 protein expressions, and HSP70 and HSP27 protein expressions indicate that the increased HSP70 expression measured with RT-PCR and IHC is HSF-1 mediated. However, brain death induction did not have any effect on mRNA and protein expression of HSP40 or HSP27, these unchanged expression patterns of HSP40 and HSP27 suggest that these proteins are not upregulated fast enough to be involved in the recuperative cascade initiated during brain death.

The HSP family of proteins is upregulated in concert during heat-shock. We therefore investigated expression of multiple HSPs in our experimental brain death model. However, only HO-1 and HSP70 were found to be upregulated. The dissociation in induction of HSP in the various models suggests that different pathways are involved in the upregulation of these genes and depend on the initial stimulus. Yet, the effects of the increase in expression of HO-1 and HSP70 appear insufficient to counteract the detrimental effects of brain death to the donor kidney. The products of heme degradation probably mediate the protective effects of HO-1. Carbon monoxide, biliverdin and iron all have various cytoprotective effects in vitro and in vivo [44]. Part of the protection could be caused by $\mathrm{CO}$ mediated vasodilatation, anti-apoptosis or anti-inflammation. The other products of heme breakdown, iron and biliverdin, also have cytoprotective properties.
Pharmacological intervention boosting the expression of HO-1 and other HSPs prior to graft harvest could therefore be a valuable procedure to increase the performance of kidneys derived from brain dead donors. The immunoregulatory function of $\mathrm{HO}-1$ has an important role in cardiac xenograft survival [45]. Induction of HO-1 during brain death could reduce the inflammatory processes initiated in the kidney. In fact, upregulation of HO-1 in brain dead rats using cobalt protoporphyrin (CoPP) in a model of experimental renal transplantation improved allograft survival to levels comparable to the living donor [46]. Interestingly, recent observations have shown that a longer duration of brain death influences kidney graft function and survival in a positive way [47]. Kidneys derived from donors that were subjected to a longer period of brain death showed a significant increase in graft survival, possibly reflecting a renal recuperative mechanism that may be mediated by the delayed induction of HSPs. Further study is needed to evaluate the role of protective and recuperative pathways during brain death, and their influence on renal transplant outcome.

\section{Conclusion}

Renal stress caused by brain death induces expression of the cytoprotective genes HO-1 and HSP70, but not of HSP27 and HSP40. The up-regulation of these cytoprotective genes could be part of a recuperative mechanism induced by stress associated with brain death.

\section{Competing interests}

The authors declare that they have no competing interests.

\section{Authors' contributions}

$L D, E B$, and TS carried out the animal experiments, the Western blotting, immunohistochemistry, and the RT-PCR. HG helped to evaluate the immunohistochemistry. $\mathrm{HL}$ and $\mathrm{HK}$ conceived the study, HL, HK, RP participated in its design. $L D, E B, H K, H L$ helped to draft the manuscript. All authors read and approved the final manuscript.

\section{Acknowledgements}

We want to thank Petra Ottens for performing the brain death induction procedure.

\section{Author details}

${ }^{1}$ Departments of Surgery, University Medical Center Groningen, University of Groningen, Hanzeplein 1, PO Box 30.001, 9700 RB Groningen, The Netherlands. ${ }^{2}$ Pathology and Laboratory Medicine, University Medical Center Groningen, University of Groningen, Hanzeplein 1, PO Box 30.001, 9700 RB Groningen, The Netherlands. ${ }^{3}$ Radiation and Stress Cell Biology, University Medical Center Groningen, University of Groningen, Hanzeplein 1, PO Box 30.001, 9700 RB Groningen, The Netherlands.

Received: 26 September 2012 Accepted: 25 January 2013

Published: 29 January 2013

\section{References}

1. Terasaki PI, Cecka JM, Gjertson DW, Takemoto S: High survival rates of kidney transplants from spousal and living unrelated donors. N Engl J Med 1995, 333(6):333-336. 
2. Hariharan S, Johnson CP, Bresnahan BA, Taranto SE, Mclntosh MJ, Stablein $D$ : Improved graft survival after renal transplantation in the United States,1988 to 1996. N Engl J Med 2000, 342(9):605-612.

3. Takada M, Nadeau KC, Hancock WW, Mackenzie HS, Shaw GD, Waaga AM, et al: Effects of explosive brain death on cytokine activation of peripheral organs in the rat. Transplantation 1998, 65(12):1533-1542.

4. Herijgers $P$, Leunens V, Tjandra-Maga TB, Mubagwa K, Flameng W: Changes in organ perfusion after brain death in the rat and its relation to circulating catecholamines. Transplantation 1996, 62(3):330-335.

5. Lopau K, Mark J, Schramm L, Heidbreder E, Wanner C: Hormonal changes in brain death and immune activation in the donor. Transpl Int 2000, 13(Suppl 1):S282-S285.

6. Van Der Hoeven JA, Molema G, Ter Horst GJ, Freund RL, Wiersema J, Van Schilfgaarde $\mathrm{R}$, et al: Relationship between duration of brain death and hemodynamic (in)stability on progressive dysfunction and increased immunologic activation of donor kidneys. Kidney Int 2003, 64(5):1874-1882.

7. Van Der Hoeven JA, Ploeg RJ, Postema F, Molema I, de Vos P, Girbes AR, et al: Induction of organ dysfunction and up-regulation of inflammatory markers in the liver and kidneys of hypotensive brain dead rats: a model to study marginal organ donors. Transplantation 1999, 68(12):1884-1890.

8. Koo DD, Welsh Kl, McLaren AJ, Roake JA, Morris PJ, Fuggle SV: Cadaver versus living donor kidneys: impact of donor factors on antigen induction before transplantation. Kidney Int 1999, 56(4):1551-1559.

9. Van Der Hoeven JA, Moshage H, Schuurs T, Nijboer M, Van Schilfgaarde R, Ploeg RJ: Brain death induces apoptosis in donor liver of the rat. Transplantation 2003, 76(8):1150-1154.

10. Beck FX, Neuhofer W, Muller E: Molecular chaperones in the kidney: distribution, putative roles, and regulation. Am J Physiol Renal Physio 2000, 279(2):F203-F215.

11. Fink AL: Chaperone-mediated protein folding. Physiol Rev 1999, 79(2):425-449.

12. Pockley AG: Heat shock proteins as regulators of the immune response. Lancet 2003, 362(9382):469-476.

13. Millar DG, Garza KM, Odermatt B, Elford AR, Ono N, Li Z, et al: Hsp70 promotes antigen-presenting cell function and converts T-cell tolerance to autoimmunity in vivo. Nat Med 2003, 9(12):1469-1476.

14. Asea A, Kraeft SK, Kurt-Jones EA, Stevenson MA, Chen LB, Finberg RW, et al: HSP70 stimulates cytokine production through a CD14-dependant pathway, demonstrating its dual role as a chaperone and cytokine. Nat Med 2000, 6(4):435-442.

15. Gowda A, Yang C, Asimakis GK, Rastegar S, Motamedi M: Heat shock improves recovery and provides protection against global ischemia after hypothermic storage. Ann Thorac Surg 1998, 66(6):1991-1997.

16. Hiratsuka M, Mora BN, Yano M, Mohanakumar T, Patterson GA: Gene transfer of heat shock protein 70 protects lung grafts from ischemiareperfusion injury. Ann Thorac Surg 1999, 67(5):1421-1427.

17. Komatsuda A, Wakui $H$, Oyama $Y$, Imai $H$, Miura $A B$, Itoh $H$, et al: Overexpression of the human $72 \mathrm{kDa}$ heat shock protein in renal tubular cells confers resistance against oxidative injury and cisplatin toxicity. Nephrol Dial Transplant 1999, 14(6):1385-1390.

18. Pileggi A, Molano RD, Berney T, Cattan P, Vizzardelli C, Oliver R, et al: Heme oxygenase-1 induction in islet cells results in protection from apoptosis and improved in vivo function after transplantation. Diabetes 2001, 50(9):1983-1991.

19. Perdrizet GA, Kaneko H, Buckley TM, Fishman MS, Pleau M, Bow L, et al: Heat shock and recovery protects renal allografts from warm ischemic injury and enhances HSP72 production. Transplant Proc 1993, 25(1 Pt 2):1670-1673.

20. Hiratsuka M, Yano M, Mora BN, Nagahiro I, Cooper JD, Patterson GA: Heat shock pretreatment protects pulmonary isografts from subsequent ischemia-reperfusion injury. J Heart Lung Transplant 1998, 17(12):1238-1246.

21. Redaelli CA, Wagner M, Kulli C, Tian YH, Kubulus D, Mazzucchelli L, et al: Hyperthermia-induced HSP expression correlates with improved rat renal isograft viability and survival in kidneys harvested from non-heartbeating donors. Transpl Int 2001, 14(6):351-360.

22. Redaelli CA, Tien YH, Kubulus D, Mazzucchelli L, Schilling MK, Wagner AC: Hyperthermia preconditioning induces renal heat shock protein expression, improves cold ischemia tolerance, kidney graft function and survival in rats. Nephron 2002, 90(4):489-497.
23. Wagner M, Cadetg P, Ruf R, Mazzucchelli L, Ferrari P, Redaelli CA: Heme oxygenase-1 attenuates ischemia/reperfusion-induced apoptosis and improves survival in rat renal allografts. Kidney Int 2003, 63(4):1564-1573.

24. Tullius SG, Nieminen-Kelha M, Buelow R, Reutzel-Selke A, Martins PN, Pratschke J, et al: Inhibition of ischemia/reperfusion injury and chronic graft deterioration by a single-donor treatment with cobaltprotoporphyrin for the induction of heme oxygenase- 1 . Transplantation 2002, 74(5):591-598.

25. Araujo JA, Meng L, Tward AD, Hancock WW, Zhai Y, Lee A, et al: Systemic rather than local heme oxygenase-1 overexpression improves cardiac allograft outcomes in a new transgenic mouse. J Immunol 2003, 171(3):1572-1580.

26. Katori M, Buelow R, Ke B, Ma J, Coito AJ, lyer S, et al: Heme oxygenase-1 overexpression protects rat hearts from cold ischemia/reperfusion injury via an antiapoptotic pathway. Transplantation 2002, 73(2):287-292.

27. Redaelli CA, Tian YH, Schaffner T, Ledermann M, Baer HU, Dufour JF: Extended preservation of rat liver graft by induction of heme oxygenase-1. Hepatology 2002, 35(5):1082-1092.

28. Willis D, Moore AR, Frederick R, Willoughby DA: Heme oxygenase: a novel target for the modulation of the inflammatory response. Nat Med 1996, 2(1):87-90.

29. Woo J, lyer S, Cornejo MC, Mori N, Gao L, Sipos I, et al: Stress proteininduced immunosuppression: inhibition of cellular immune effector functions following overexpression of haem oxygenase (HSP 32). Transpl Immunol 1998, 6(2):84-93.

30. Schuurs TA, Gerbens F, van der Hoeven JA, Ottens PJ, Kooi KA, Leuvenink $H G$, et al: Distinct transcriptional changes in donor kidneys upon brain death induction in rats: insights in the processes of brain death. Am J Transplant 2004, 4(12):1972-1981.

31. Yuan $X Q$, Wade $C E$, Prough DS, DeWitt DS: Traumatic brain injury creates biphasic systemic hemodynamic and organ blood flow responses in rats. J Neurotrauma 1990, 7(3):141-153.

32. Pratschke J, Wilhelm MJ, Kusaka M, Beato F, Milford EL, Hancock WW, et al: Accelerated rejection of renal allografts from brain-dead donors. Ann Surg 2000, 232(2):263-271.

33. Pratschke J, Wilhelm MJ, Laskowski I, Kusaka M, Beato F, Tullius SG, et al: Influence of donor brain death on chronic rejection of renal transplants in rats. J Am Soc Nephrol 2001, 12(11):2474-2481.

34. Morimoto K, Ohta K, Yachie A, Yang Y, Shimizu M, Goto C, et al: Cytoprotective role of heme oxygenase (HO)-1 in human kidney with various renal diseases. Kidney Int 2001, 60(5):1858-1866.

35. Takano T, Yonemitsu Y, Saito S, Itoh H, Onohara T, Fukuda A, et al: A somatostatin analogue, octreotide, ameliorates intestinal ischemiareperfusion injury through the early induction of heme oxygenase- 1 . J Surg Res 2012, 175(2):350-358.

36. Shimizu H, Takahashi T, Suzuki T, Yamasaki A, Fujiwara T, Odaka Y, et al: Protective effect of heme oxygenase induction in ischemic acute renal failure. Crit Care Med 2000, 28(3):809-817.

37. Agarwal A, Kim Y, Matas AJ, Alam J, Nath KA: Gas-generating systems in acute renal allograft rejection in the rat. Co-induction of heme oxygenase and nitric oxide synthase. Transplantation 1996, 61(1):93-98.

38. Muller E, Neuhofer W, Ohno A, Rucker S, Thurau K, Beck FX: Heat shock proteins HSP25, HSP60, HSP72, HSP73 in isoosmotic cortex and hyperosmotic medulla of rat kidney. Pflugers Arch 1996, 431(4):608-617.

39. Cittanova ML, Leblanc I, Legendre C, Mouquet C, Riou B, Coriat P: Effect of hydroxyethylstarch in brain-dead kidney donors on renal function in kidney-transplant recipients. Lancet 1996, 348(9042):1620-1622.

40. Schortgen F, Lacherade JC, Bruneel F, Cattaneo I, Hemery F, Lemaire F, et al: Effects of hydroxyethylstarch and gelatin on renal function in severe sepsis: a multicentre randomised study. Lancet 2001, 357(9260):911-916.

41. Yeh T Jr, Wechsler AS, Graham L, Loesser KE, Sica DA, Wolfe L, et al: Acute brain death alters left ventricular myocardial gene expression. $J$ Thorac Cardiovasc Surg 1999, 117(2):365-374.

42. Valles P, Jorro F, Carrizo L, Manucha W, Oliva J, Cuello-Carrion FD, et al: Heat shock proteins HSP27 and HSP70 in unilateral obstructed kidneys. Pediatr Nephrol 2003, 18(6):527-535.

43. Soares MP, Lin Y, Anrather J, Csizmadia E, Takigami K, Sato K, et al: Expression of heme oxygenase-1 can determine cardiac xenograft survival. Nat Med 1998, 4(9):1073-1077.

44. Ollinger $\mathrm{R}$, Pratschke $\mathrm{J}$ : Role of heme oxygenase- 1 in transplantation. Transpl Int 2010, 3(11):1071-1081. 
45. Rochet J: Novel therapeutic strategies for the treatment of proteinmisfolding diseases. Expert Rev Mol Med 2007, 28;9(17):1-34.

46. Kotsch K, Francuski M, Pascher A, Klemz R, Seifert M, Mittler J, et al: Improved Long-Term Graft Survival after HO-1 Induction in Brain-Dead Donors. Am J Transplant 2006, 6(3):477-486.

47. Kunzendorf U, Hohenstein B, Oberbarnscheid M, Muller E, Renders L, Schott $\mathrm{GE}$, et al: Duration of donor brain death and its influence on kidney graft function. Am J Transplant 2002, 2(3):292-294.

doi:10.1186/1479-5876-11-22

Cite this article as: van Dullemen et al:: Brain death induces renal

expression of heme oxygenase-1 and heat shock protein 70. Journal of

Translational Medicine 2013 11:22.

\section{Submit your next manuscript to BioMed Central and take full advantage of:}

- Convenient online submission

- Thorough peer review

- No space constraints or color figure charges

- Immediate publication on acceptance

- Inclusion in PubMed, CAS, Scopus and Google Scholar

- Research which is freely available for redistribution 